\title{
INTEGRASI RISK BASED THINKING DENGAN PROCESS APPROACH DALAM PERENCANAAN DAN PENERAPAN SISTEM MANAJEMEN MUTU ISO $9001: 2015$
}

\author{
Pongky Lubas Wahyudi ${ }^{1}$, Dian Setiya Widodo ${ }^{2}$
}

Teknik Manufaktur

Politeknik 17 Agustus 1945 Surabaya, Indonesia

e-mail : 1pongkywahyudi2017@gmail.com,2diansetiyawidodo@yahoo.com

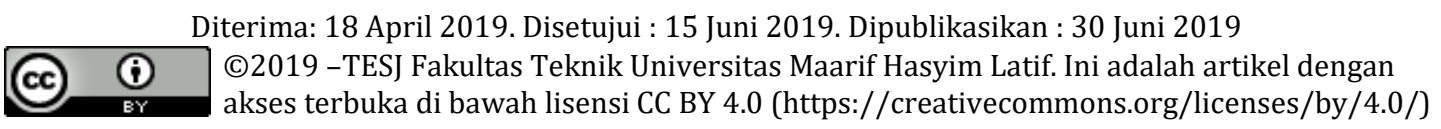

ABSTRAK

Penjaminan mutu dalam industri sangat penting dan menjadi perhatian utama untuk kelangsungan bisnisnya. Perusahaan dituntut untuk melakukan efisiensi di segala bidang dengan meningkatkan kualitas tenaga kerja dan produk yang dihasilkan dan hal tersebut dapat dilakukan dengan penerapan sistem manajemen mutu ISO 9001:2015. Salah satu perubahan signifikan dalam ISO 9001:2015 adalah peningkatan fokus pemikiran berbasis risiko dalam persyaratan perencanaan, peninjauan dan peningkatan sistem manajemen mutu (SMM) dan prosesnya. Hal ini dianggap sebagai tantangan yang signifikan untuk manajemen yang berusaha untuk mengimplementasikan risk based thinking yang berkaitan dengan SMM organisasi. Tujuan penelitian ini, menerapkan risk based thinking dengan pendekatan proses dalam mengidentifikasi potensi risiko, dampak dan tindakan pengendalian yang diperlukan terutama di departemen produksi. Metode yang digunakan pengumpulan data kualitatif dari berbagai sumber, seperti literatur. Data dikumpulkan dari hasil wawancara, diskusi dengan semua elemen organisasi dan langkah-langkahnya dalam menentukan tiap risiko di departemen produksi. Hasil diskusi akan dibandingkan dengan standar dan literatur yang ada. Unsur yang mendasari untuk melakukan risk based thinking diidentifikasi sebagai; proses/kegiatan organisasi, organisasi, budaya, kompetensi, manajemen, dan pihak yang berkepentingan. Hasil identifikasi risiko di departemen produksi terdapat 7 risiko dengan 1 risiko tingkat tinggi dan tidak dapat diterima (not acceptance). Rekomendasi perbaikan yang dilakukan adalah mengganti dies yang telah aus pada mesin injection moulding sehingga permasalahan tersebut dapat diselesaikan. Analisa risiko yang telah dibuat, disarankan untuk diperbaharui secara berkala minimal setahun sekali. Sedangkan rencana rekomendasi perbaikan yang dinilai berhasil dapat dilanjutkan dan dikembangkan, namun bila dinilai tidak berhasil disarankan untuk mencari rencana rekomendasi perbaikan yang lainnya.

Kata kunci: ISO 9001:2015, manajemen risiko, smm, risk based thinking

\section{PENDAHULUAN}

Pertumbuhan industri yang sangat pesat akhir-akhir ini merupakan tantangan terbesar bagi suatu perusahaan untuk memenangkan persaingan dan menjamin kepuasan pelanggan baik itu dari segi jasa ataupun produk yang dihasilkannya. Salah satu perusahaan manufaktur yang bergerak di bidang plastic injection moulding yang mempunyai keinginan untuk terus berkembang dan memposisikan perusahaannya sebagai perusahaan yang mampu bersaing dan berkembang secara berkelanjutan. Untuk mewujudkan keinginanya perusahaan telah banyak melakukan perubahanperubahan perbaikan disegala bidang dengan melakukan program continous improvement serta perusahan terus berupaya untuk selalu meningkatkan kinerja dari para karyawannya baik kinerja personal (individu) maupun kinerja dari organisasi organisasi yang ada didalamnya. Salah satu langkah awal yang diambil perusahaan adalah berusaha mendapatkan sertifikasi ISO 9001:2015 dari badan sertifikasi nasional dimana persiapan yang telah dilakukan berjalan dengan baik dan lancar walaupun memerlukan waktu yang agak lama. Perusahaan yang telah mendapatkan sertifikasi ISO 9001:2015 dikategorikan sebagai perusahaaan yang menghasilkan produk dan pelayanan terhadap pelanggan telah sesuai standar yang sudah diakui secara internasional. Proses selanjutnya diharapkan seluruh karyawan dapat menerapkan prosedur yang menjadi persyaratan standard ISO secara konsisten dan berkelanjutan. 
Proses penting dalam implementasi ISO 9001:2015 adalah bagaimana merencanakan dan menerapkan manajemen risiko sebagai bagian dari Risk based thinking terhadap proses manufaktur yang diselenggarakan. Risk based thinking dievaluasi minimal setahun sekali untuk memastikan bahwa setiap risiko pekerjaan yang dilaksanakan dapat dimanage atau dikontrol dengan baik sehingga sistem manajemen mutu dapat selalu dipelihara dan dilaksanakan secara konsisten dan berkelanjutan.

Risk based thinking memungkinkan suatu organisasi untuk menentukan faktor yang dapat mempengaruhi keberlangsungan proses serta sistem manajemen mutunya, yang mengarah ke penyimpangan dari hasil yang direncanakan dan menempatkan usaha pencegahan untuk meminimalkan efek negatif ketika risk muncul. Sebenarnya Risk based thinking adalah sesuatu hal biasa yang dilakukan dalam kehidupan sehari-hari seperti dalam merencanakan pekerjaan, sekolah dan berpergian dimana risiko yang akan terjadi tentunya selalu akan menjadi pertimbangan untuk diminimalkan terjadi atau dihindari dan mungkin saja ditiadakan.

\section{METODE PENELITIAN}

Metode yang dipakai dalam penelitian Integrasi Pemikiran Berbasis Risiko dengan Process Approach dijabarkan dalam 5 (lima) tahapan seperti pada Gambar 1.

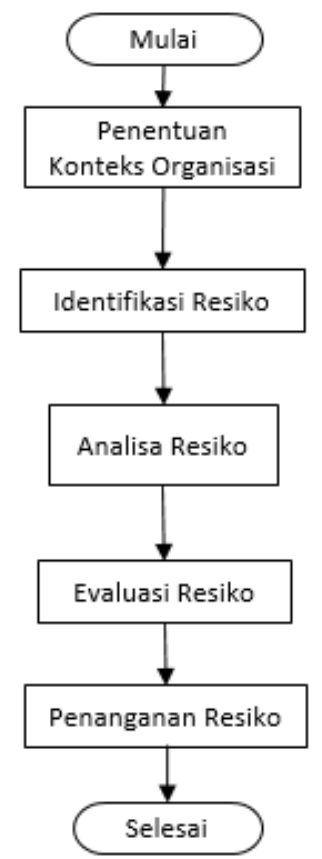

Gambar 1. Flow Chart Metodologi Penelitian

Kelima tahapan tersebut : penetapan konteks organisasi; identifikasi risiko; analisa risiko; evaluasi risiko; dan penanganan risiko.
Harus dimanage oleh sumber daya manusia yang terlatih serta sebuah sistem yang dibangun dengan baik agar dapat membantu perusahaan secara kontinyu mengevaluasi kelemahan dan kekuatan yang dimilikinya, sehingga perusahaan akan memiliki struktur bisnis yang kuat dalam menghadapi setiap tantangan yang ada dan dapat bertahan dan terus berkembang dalam berbagai situasi dan kondisi.

\section{Menentukan Konteks Organisasi}

Penetapan konteks organisasi dapat mengacu pada rencana jangka panjang perusahaan, key performance indicator setiap departemen yang ada maupun visi dan misi perusahaan. Langkah-langkah dalam menentukan konteks adalah sebagai berikut:

a. identifikasi pihak berkepentingan

b. menentukan issue internal dan eksternal

c. harapan pihak-pihak berkepentingan

\section{Identifikasi Risiko}

Mengidentifikasi Risiko adalah proses melakukan pencarian, pengenalan dan pendeskripsian risiko yang dapat berdampak pada kemampuan perusahaan dalam mencapai tujuannya. Dalam hal ini setiap departemen melakukan identifikasi sumber potensi risiko dari setiap proses dan kegiatan yang ada menggunakan bantuan turtle diagram. Identifikasi potensi risiko mencakup kegiatan rutin, non rutin, darurat (emergency), Kegiatan seluruh karyawan yang di tempat kerja (termasuk sub kontraktor dan tamu), fasilitas di tempat kerja dan lain-lainnya. Langkahlangkah Proses Identifikasi Risiko adalah sebagai berikut :

a. Menentukan unit risiko.

Misalnya identifikasi risiko akan dilakukan di departemen produksi, maka risk owner-nya adalah departemen produksi.

b. Memahami proses bisnis.

Proses bisnis harus dipahami dengan baik ketika akan melakukan identifikasi risiko. Seluruh detail pekerjaan atau kegiatan pada satu unit bisnis perlu dikaji dengan dalam sehingga nantinya seluruh potensi risiko yang ada dapat teridentifikasi. Pada umumnya, proses bisnis terdiri dari 2 kelompok pekerjaan atau kegiatan, yaitu pekerjaan utama dan pekerjaan pendukung.

c. Menentukan pekerjaan yang kritikal.

Yang dikatakan kritikal adalah efek yang ditimbulkan oleh risiko yang ada dapat mengganggu atau bahkan berhentinya suatu pekerjaan atau dengan kata lain aktivitas pekerjaan tersebut tidak berjalan sebagaimana mestinya.

d. Menentukan bentuk-bentuk kerugian yang mungkin terjadi. 
- Kerugian yang terjadi pada orang misalnya : cedera, sakit, meninggal dan berhenti bekerja

- Kerugian pada barang misalnya : hilang, rusak, aus, tidak sesuai, terbakar, kualitasnya jelek, dicuri dan diselewengkan.

e. Menentukan penyebab risiko terjadi :

- Faktor manusia misalnya : selera, kompetensi, moral.

- Faktor teknologi misalnya : kesesuaian, keusangan, kualitas.

- Faktor alam misalnya : bencana alam, cuaca, kelembaban, kondisi alam.

\section{Analisa/Penilaian Risiko}

Penilaian risiko dilakukan dengan mempertimbangkan :

a. Tingkat kejadian (occurence) : nilai perkiraan seberapa besar kemungkinan kejadian tersebut dapat terjadi.

b. Tingkat keseriusan dampak (severity) : nilai perkiraan seberapa besar dampak dari kerugian yang di timbulkan.

c. Penilaian risiko dapat diperoleh dengan rumus :

$$
\text { NILAI RISIKO }=\text { OCCURRENCE } \times \text { SEVERITY }
$$

\section{Evaluasi Risiko}

Mengevaluasi Risiko adalah proses untuk membandingkan hasil dari analisa risiko dengan menetapkan kriteria apakah level dari risiko tersebut tergolong dalam risiko yang dapat diterima atau tidak. Jika risiko berada pada level yang tidak dapat diterima (not acceptable) maka harus ditentukan rencana tindakan perbaikan.

Risiko berada pada level yang dapat diterima (acceptable) apabila :

1. Hasil penilaian/evaluasi level risiko rendah sehingga tidak memerlukan penanganan khusus;

2. Tidak ada penanganan untuk risiko;

3. Biaya penanganan lebih tinggi daripada nilai manfaat yang diperoleh;

4. Peluang dari adanya risiko tersebut lebih besar dari dampaknya.

Langkah evaluasi dilakukan untuk memastikan bahwa tidak semua risiko yang teridentifikasi memerlukan rencana penanganan lebih lanjut.

Unit kerja sebagai penanggung jawab validasi risiko yang hasil validasi itu nantinya akan digu-nakan untuk membuat dan menetapkan rencana pengendalian sistem untuk menurunkan kemung-kinan terjadinya risiko ataupun menurunkan dampak terjadinya risiko.

\section{Penanganan Risiko}

Hierarki penanganan/pengendalian risiko adalah sebagai berikut:

a. Menghindari risiko (avoid) :
Menghilangkan kegiatan/proses yang menimbulkan dampak risiko terhadap mutu, di luar kemampuan organisasi untuk menanggungnya.

b. Mengurangi risiko :

Mengurangi tingkat kejadian (occurance) atas suatu risiko dapat dilakukan dengan cara berupa pelatihan, perbaikan proses, penambahan prosedur baru. Mengurangi tingkat keseriusan dampak (severity) atas suatu risiko dapat dilakukan dengan cara berupa menyediakan cadangan sumber daya, membeli alat baru.

c. Mengalihkan/sharing beban risiko :

Risk Owner dapat memutuskan untuk mengurangi impact suatu risiko dengan cara mengalihkan atau membagi beban risiko kepada pihak lain (misal: outsourcing, asuransi, subcontractor. ).

d. Menerima risiko :

Mempertahankan risiko pada tingkat saat ini. pilihan ini dapat dilakukan untuk risiko yang mempunyai level risiko sangat rendah.

\section{HASIL DAN PEMBAHASAN}

\section{Tahap 1 :Menentukan Konteks}

a. Identifikasi Pihak Berkepentingan

Mereka yang memberikan risiko signifikan terhadap keberlanjutan organisasi (jika kebutuhan dan harapan mereka tidak dipenuhi) disebut sebagai Pihak yang berkepentingan. Hasil ketetapan organisasi mengenai hal yang relevan perlu disampaikan ke pihak berkepen-tingan untuk mengurangi risiko tersebut. Dalam melakukan identifikasi pihak berkepentingan, langkah awal yang harus dilakukan adalah melakukan diskusi internal dengan semua pihak untuk membuat dan memutuskan daftar pihakpihak yang berkepentingan sebagimana pada Tabel 1.

Tabel 1. Daftar Pihak Berkepentingan
\begin{tabular}{|l|}
\hline Daftar Pihak Berkepentingan \\
\hline Direksi/Owner \\
\hline Karyawan \\
\hline Pemerintah \\
\hline Supplier \\
\hline Customer \\
\hline
\end{tabular}

\section{b. Menentukan Issue Internal dan Eksterna}

Kemampuan organisasi untuk mencapai hasil yang diharapkan dari sistem manajemen mutunya, dipengaruhi oleh pemahaman yang baik tentang masalah eksternal dan internal yang relevan dengan tujuan strategis organisasi. Data tentang masalah eksternal dan internal dapat dikumpulkan dari berbagai sumber, seperti melalui : rapat atau pertemuan dengan instansi/departemen terkait, pertemuan dengan 
vendor atau supplier, pertemuan internal organisasi yang terdokumentasi, pertemuan dengan masyarakat sekitar, pertemuan dengan pelanggan dan pihak yang berkepentingan terkait, sehingga didapatkan hasil pada Tabel 2.

Tabel 2. Issue Internal dan Eksternal

\begin{tabular}{|l|l|}
\hline \multicolumn{1}{|c|}{ Issue Internal } & \multicolumn{1}{c|}{ Issue Eksternal } \\
\hline 1. Sumber daya & 1. Kebijaksanaan Pemerintah \\
-Karyawan/pekerja & 2. Hubungan Sosial \\
-Mesin & 3. Kemampuan Supplier \\
- Sarana dan Prasarana & 4. Perkembangan Teknologi \\
2. Kemampuan Internal & 5. Keluhan Pelanggan \\
\hline
\end{tabular}

Kemudian Manajemen Representative dan Top Manajemen melakukan penilaian level risiko, berikut Tabel 3 hasil penilaian risiko pada issue internal dan eksternal.

Tabel 3. Penilaian risiko Issue Internal dan Eksternal

\begin{tabular}{|c|c|}
\hline Level & \multicolumn{1}{c|}{ Deskripsi } \\
\hline \multirow{2}{*}{ Tinggi } & $\begin{array}{l}\text { 1. Issue Internal dan eksternal tersebut berpotensi mengakibatkan } \\
\text { berhentinya operasional }\end{array}$ \\
\cline { 2 - 3 } ( T) & $\begin{array}{c}\text { 2. Issue Internal dan eksternal tersebut berpotensi mengakibatkan } \\
\text { pelanggaran atas undang - undang yang berlaku termasuk } \\
\text { lingkungan yang ditimbulkan operasional perusahan }\end{array}$ \\
\hline \multirow{2}{*}{ Sedang } & $\begin{array}{l}\text { 1. Issue Internal dan eksternal tersebut berpotensi mengakibatkan } \\
\text { berhentinya operasional sebagian kecil proses bisnis perusahaan }\end{array}$ \\
\cline { 2 - 3 } ( S) & $\begin{array}{l}\text { 2. Issue Internal dan eksternal tersebut mempengaruhi kebijakan } \\
\text { perusahaan jangka pendek baik secara aspek bisnis dan aspek } \\
\text { lingkungan }\end{array}$ \\
\hline \multirow{2}{*}{ Rendah } & $\begin{array}{l}\text { 1. Issue Internal dan eksternal tersebut tidak mempengaruhi } \\
\text { secara langsung jalannya perusahaan namun perlu perhatian. }\end{array}$ \\
\cline { 2 - 3 } ( R ) & $\begin{array}{l}\text { 2. Issue Internal dan eksternal tersebut mempengaruhi kebijakan } \\
\text { perusahaan jangka panjang baik secara aspek bisnis dan aspek } \\
\text { lingkungan }\end{array}$ \\
\hline
\end{tabular}

c. Harapan Pihak-Pihak Berkepentingan

Untuk memahami kebutuhan dan harapan pihak-pihak berkepentingan, beberapa kegiatan dan metode yang dilakukan adalah : melakukan survei pelanggan, melakukan pemeriksaan order yang masuk, benchmarking dengan perusahaan serupa, meninjau persyaratan undang-undang dan kepatuhan terhadap hukum dan peraturan terkait, memonitor kebutuhan, harapan dan kepuasan pelanggan mengenai kesesuaian, harga, ketersediaan atau pengiriman, kesepakatan dengan kelompok masyarakat atau organisasi non-pemerintah, kewajiban yang timbul berdasarkan perjanjian kontrak dengan organisasi, dan kebijakan organisasi untuk karyawan. Hasilnya didapatkan pada Tabel 4.

Tahapan selanjutnya adalah merangkum daftar pihak berkepentingan, issue internal dan eksternal dan harapan pihak-pihak berkepentingan di dalam suatu Tabel 5 dimana ditambahkan peluang, potensi dan dampak risiko dan level risikonya.

\section{Tahap 2 : Identifikasi Risiko}

Identifikasi risiko dilakukan dengan langkah-langkah menentukan unit risiko, memahami proses bisnis, menentukan aktivitas yang krusial, menentukan bentuk kerugian yang dapat terjadi, dan menentukan penyebab terjadinya risiko manusia : kompetensi, moral, selera, serta teknologi. Ke semua kreteria di atas dituangkan dalam turtle diagram lewat brainstorming untuk memvisualisasikan dan dapat dengan mudah dipahami dan dimengerti.

Tabel 4. Harapan Pihak-Pihak Berkepentingan

\begin{tabular}{|c|c|}
\hline Pihak Berkepentingan & Harapannya \\
\hline \multirow{3}{*}{ Karyawan } & Jaminan kesehatan kerja \\
\hline & $\begin{array}{l}\text { Jaminan keamanan dan keselamatan ker- } \\
\text { ja }\end{array}$ \\
\hline & Jaminan kesejahteraan ekonomi \\
\hline \multirow{6}{*}{ Pelanggan } & Jaminan kualitas \\
\hline & Jaminan ketersediaan barang \\
\hline & Jaminan ketepatan pengiriman \\
\hline & Jaminan harga kompetitif \\
\hline & $\begin{array}{l}\text { Jaminan pelayanan yang baik dan respon } \\
\text { yang cepat }\end{array}$ \\
\hline & Bersertifikasi ISO \\
\hline \multirow{11}{*}{ Direksi / Owner } & $\begin{array}{l}\text { Kebijaksanaan pemerintah yang men- } \\
\text { dukung industri }\end{array}$ \\
\hline & Peningkatan image perusahaan \\
\hline & $\begin{array}{l}\text { Lingkungan sekitar yang aman dan kon- } \\
\text { dusif }\end{array}$ \\
\hline & $\begin{array}{l}\text { Komunikasi dan hubungan yang baik } \\
\text { dengan masyarakat di sekitar }\end{array}$ \\
\hline & Peluang pekerjaan \\
\hline & Harga yang kompetitif \\
\hline & Pertumbuhan laba \\
\hline & Perluasan pasar dan penjualan \\
\hline & Team work yang solid \\
\hline & Sumber daya yang memadai, kompetitif \\
\hline & Awareness karyawan \\
\hline \multirow{2}{*}{ Supplier } & Pembayaran sesuai jadwal \\
\hline & Order berkelanjutan \\
\hline \multirow{3}{*}{ Pemerintah } & Pemenuhan UU No. 13 tahun 2003 \\
\hline & $\begin{array}{l}\text { Pemenuhan regulasi baik Propinsi dan } \\
\text { Kabupaten (lokal) }\end{array}$ \\
\hline & $\begin{array}{l}\text { Kepatuhan pembayaran pajak dan pen- } \\
\text { gurusan perijinan (lokal) }\end{array}$ \\
\hline
\end{tabular}

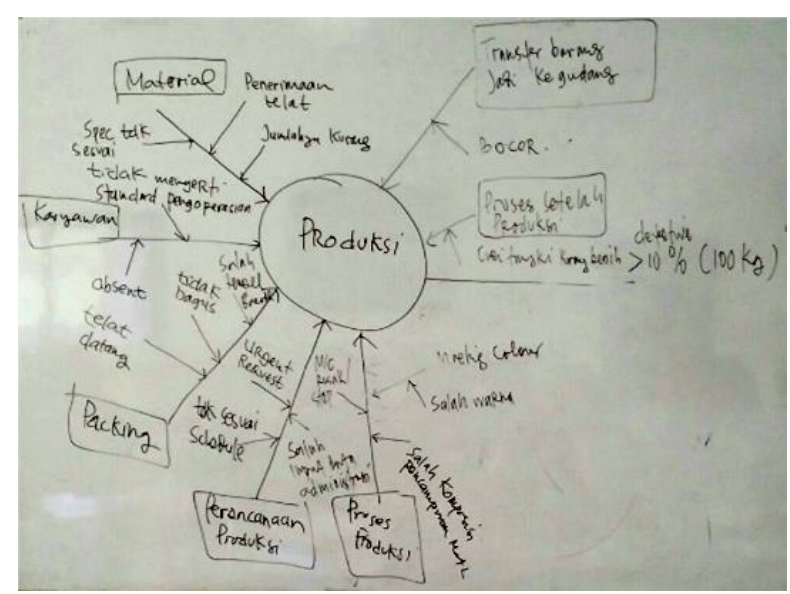

Gambar 2. Identifikasi Risiko dengan Turtle Diagram 
Tabel 5. Konteks Organisasi

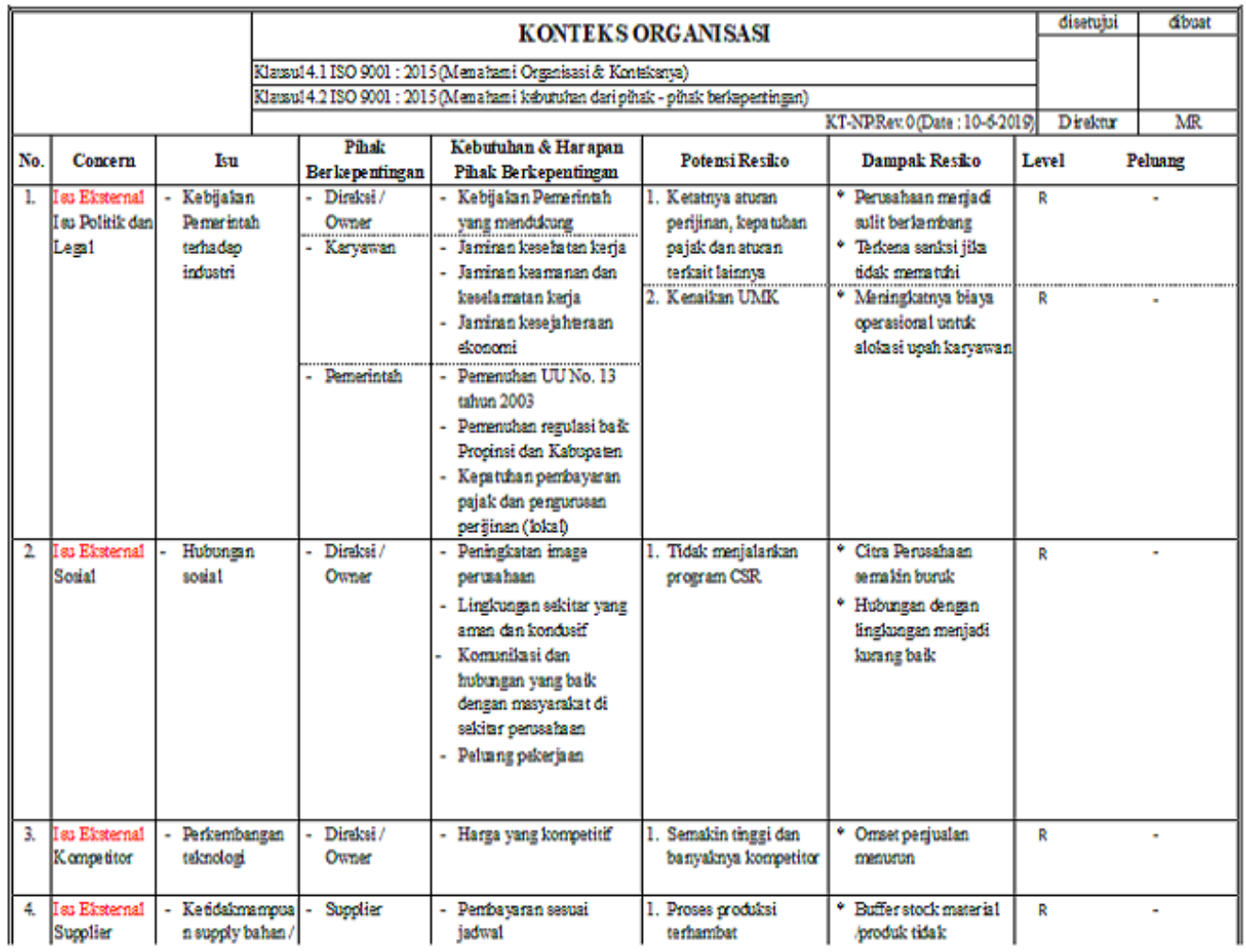

\section{Tahap 3: Analisa/Penilaian Risiko}

Penilaian risiko dilakukan dengan mempertimbangkan Tingkat kejadian (occurence) : nilai perkiraan seberapa besar kemungkinan kejadian tersebut dapat terjadi dan Tingkat keseriusan dampak (severity) : nilai perkiraan seberapa besar dampak dari kerugian yang ditimbulkan, dapat dideskripsikan pada Tabel 6.

\begin{tabular}{|c|c|c|c|c|c|}
\hline Nilai & 1 & 2 & 3 & 4 & 5 \\
\hline Financial & $0-20$ juta & $21-50$ juta & $51-100$ juta & $101-250$ juta & $>250$ juta \\
\hline $\begin{array}{l}\text { Reputasi } \\
\text { organisasi }\end{array}$ & $\begin{array}{l}\text { publisitas jelek } \\
\text { di internal } \\
\text { perusahaan }\end{array}$ & \begin{tabular}{|c|} 
publistas jelek \\
di media lokal
\end{tabular} & $\begin{array}{l}\text { publisitas jelek } \\
\text { di media } \\
\text { propinsi }\end{array}$ & $\begin{array}{l}\text { publisitas } \\
\text { jelek di } \\
\text { media } \\
\text { nasional }\end{array}$ & \begin{tabular}{|l|} 
publist as \\
jelek di media \\
internasional
\end{tabular} \\
\hline Produksi & $\begin{array}{l}\text { Pabrik } \\
\text { beroperasi } \\
\text { normal } \\
\text { dengan } \\
\text { gangguan } \\
\text { tidzk berarti }\end{array}$ & \begin{tabular}{|l|} 
Pabrik \\
beroperasi \\
normal \\
dengan \\
gangguan yang \\
menyebabkan \\
perbaikan di \\
tempat
\end{tabular} & \begin{tabular}{|l|} 
Pabrik \\
beroperæi tidak \\
normal, per lu \\
perbaikan \\
dengan \\
menurunkan \\
rate produksi
\end{tabular} & \begin{tabular}{|l|} 
Pabrik \\
shutdown \\
dengan \\
kerusakan \\
yang \\
memer lukan \\
perbaikan \\
selama 5 hai
\end{tabular} & \begin{tabular}{|l|} 
Pabrik \\
shut down \\
dengan \\
kerusakan \\
yang \\
memerlukan \\
perbakan \\
lebih dari5
\end{tabular} \\
\hline
\end{tabular}

Kriteria tingkat kejadian (Occurence), dapat dideskripsikan pada Tabel 7.

Tabel 7. Tabel Occurence

\begin{tabular}{|c|l|l|}
\hline Nilai & Kriteria & Frekuensi \\
\hline 1 & Hampir tidak pernah terjadi & 1 kali dalam setahun \\
\hline 2 & Mungkin terjadi & 2-3 kali dalam setahun \\
\hline 3 & Jarang terjadi & $4-6$ kali dalam setahun \\
\hline 4 & Sering terjadi & 7-11 kali dalam setahun \\
\hline 5 & Hampir pasti terjadi & lebih dari 11 kali dalam setahun \\
\hline
\end{tabular}

Hasil penilaian risiko yang telah dilakukan ditampilkan pada Tabel 8.

Tabel 8. Hasil Penilaian Risiko

\begin{tabular}{|c|c|c|c|c|c|c|c|}
\hline & \multirow{4}{*}{ Keterangan } & & \multicolumn{5}{|c|}{ Severity } \\
\hline & & & $\begin{array}{c}\text { Tidak } \\
\text { signifikan }\end{array}$ & kecil & Sedang & Berat & Fatal \\
\hline & & Nilai & 1 & 2 & 3 & 4 & 5 \\
\hline & & Bobot & 1 & 1 & 5 & 6 & 15 \\
\hline \multirow{5}{*}{ 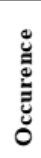 } & Hampir pasti & 5 & 5 & 10 & 75 & 120 & 375 \\
\hline & Sering & 4 & 4 & 8 & 60 & 96 & 300 \\
\hline & Jarang & 3 & 3 & 6 & 45 & 72 & 225 \\
\hline & Mungkin & 2 & 2 & 4 & 30 & 48 & 150 \\
\hline & Hampir tidak pernah & 1 & 1 & 2 & 15 & 24 & 75 \\
\hline
\end{tabular}

Jika dari hasil penilaian risiko didapatkan angka yang sama perkalian antara tingkat kejadian dan keparahan maka perusahaan mengambil tindakan untuk mengurangi tingkat keparahan terlebih dahulu.

\section{Tahap 4: Evaluasi Risiko}

Evaluasi risiko dilakukan dengan membandingkan kriteria dalam standar dengan tingkat risiko yang ada. Langkah selanjutnya hasil tingkatan risiko yang ada dari beberapa risiko yang telah ditetapkan dibuat tingkatan prioritasnya (tugas manajemen organisasi). Jika tingkat risiko yang ditetapkan levelnya rendah, maka risiko tersebut masuk ke dalam kategori yang dapat diterima (acceptable) dan tidak memerlukan penanganan atau pengendalian khusus tetapi hanya memerlukan pemantauan saja. 
Tabel 9. Kriteria Tingkat Risiko

\begin{tabular}{|c|c|c|c|}
\hline $\begin{array}{c}\text { Tingkat } \\
\text { resiko }\end{array}$ & Nilai & Kriteria & Action Plan / Reccomended Action \\
\hline $\begin{array}{c}\text { Sangat } \\
\text { rendah }\end{array}$ & $1-2$ & Acceptable & 1. Melakukan monitoring \\
\hline Rendah & $3-5$ & Acceptable & $\begin{array}{l}\text { 1. Melakukan monitoring } \\
\text { 2. Menetapkan tambahan pengendalian/ } \\
\text { merevisi prosedur }\end{array}$ \\
\hline Sedang & $6-24$ & $\begin{array}{c}\text { Not } \\
\text { Acceptable }\end{array}$ & $\begin{array}{l}\text { 1. Menentukan tindakan pengendalian } \\
\text { 2. Pemantauan pelaksanaan pengendalian } \\
\text { setiap 3 bulan }\end{array}$ \\
\hline Tinggi & $45-72$ & $\begin{array}{c}\text { Not } \\
\text { Acceptable }\end{array}$ & $\begin{array}{l}\text { 1. Menentukan tindakan pengendalian } \\
\text { 2. Pemantauan pelaksanaan pengendalian } \\
\text { setiap 2 bulan }\end{array}$ \\
\hline Ekstrim & $75-375$ & Not & $\begin{array}{l}\text { 1. Menentukan tindakan pengendalian } \\
\text { 2. Pemantauan pelaksanaan pengendalian } \\
\text { setiap 1 bulan }\end{array}$ \\
\hline
\end{tabular}

\section{Tahap 5: Pengendalian Risiko}

Hasil dari tahapan identifikasi, analisis, evaluasi, dan mitigasi/perlakuan risiko adalah berupa dokumen Daftar Pengendalian Risiko dalam Tabel 10.

Tabel 10. Daftar Pengendalian Risiko

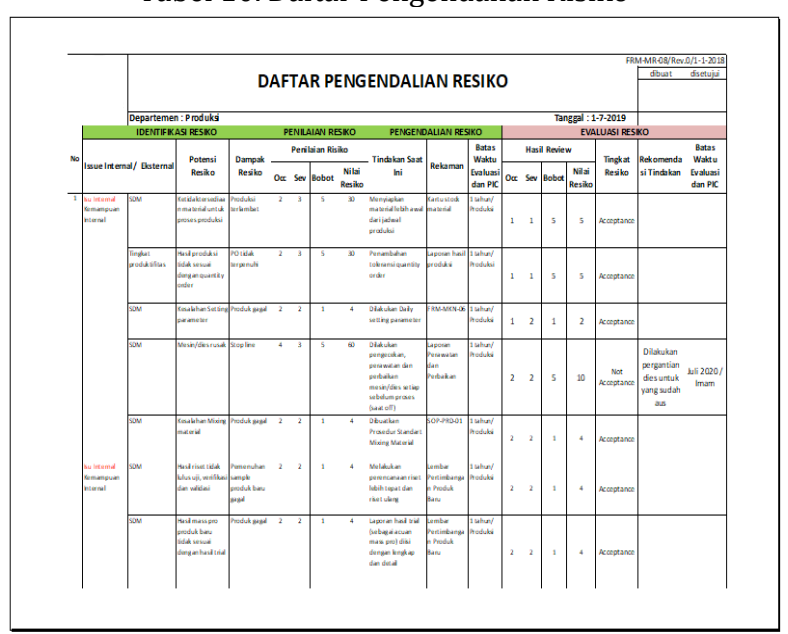

PENUTUP

Hasil identifikasi risiko di departemen produksi terdapat 7 risiko dimana 1 risiko yang tingkat risikonya tinggi dan tidak dapat diterima (not acceptance). Rekomendasi perbaikan yang dilakukan adalah mengganti dies yang telah aus pada mesin injection moulding sehingga permasalahan tersebut dapat diselesaikan.

Analisa risiko yang telah dibuat, disarankan untuk diperbaharui secara berkala minimal setahun sekali. Rencana rekomendasi perbaikan yang dinilai berhasil dapat dilanjutkan dan dikembangkan, namun bila dinilai tidak berhasil disarankan untuk mencari rencana rekomendasi perbaikan yang lainnya.

\section{DAFTAR PUSTAKA}

Chiarini, A. (2017). Risk-based thinking according to ISO 9001: 2015 standard and the risk sources European manufacturing SMEs intend to manage. The TQM Journal, 29(2), 310-323.

Hadisaputra, S., \& Kusumah, L. H. (2017). Implementasi Manajemen Risiko Berbasis ISO 9001: 2015 dan ISO 31010: 2009 Pada Usaha Jasa Konsultasi dan Pelatihan Di PT BSU Penerapan Fault Tree Analysis (FTA) Dan Failure Mode And Effect Analysis (FMEA). Prosiding SENIATI, 3(2), 41-49.

Hrbackova, L. (2016). Risk-based thinking in the production process using the methods of quality assurance matrix and the FMEA Process. Journal of Systems Integration, 7(1), 21-28.

ISO. (2015). ISO 9001:2015. Quality Management System Standard. Geneva: International Organization for Standardization (ISO).

ISO. (2018). ISO 31000:2018. Risk ManagementGuideline. Geneva: International Organization for Standardization (ISO).

Sæstad, M. (2017). Risk-Based Thinking in Quality Management, an ISO 9001: 2015 Requirement: A case study to identify underlying elements enabling risk-based thinking in organizations. Universitetet $\mathrm{i}$ Agder; University of Agder.

Sanongpong, K. (2009). Automotive product realization; a process-based management. Proceedings of the International MultiConference of Engineers and Computer Scientists, 2. 